\title{
PENGARUH FREKUENSI PENYAJIAN RANSUM YANG BERBEDA TERHADAP RASIO EFISIENSI PROTEIN, MASSA PROTEIN DAGING DAN MASSA KALSIUM DAGING AYAM KAMPUNG SUPER
}

\section{Effect of different feeding frequencies on protein efficiency ratio, meat protein mass and meat calcium mass of crossbred native chicken}

\author{
B. Wijayanto, U. Atmomarsono dan W. Sarengat \\ Fakultas Peternakan dan Pertanian, Universitas Diponegoro \\ Jalan Prof. H Soedarto, SH, Tembalang 50275, Semarang \\ e-mail : bagaskorowijayanto@gmail.com
}

\begin{abstract}
The research was aimed to evaluate the effect of different fedding frequencies to the quality of growth is protein efficiency ratio, meat protein mass and meat calcium mass of crossbred native chicken (male native chicken $x$ female laying hen). The material used was 120 unsexed birds with average body weight 97,49 $\pm 5,40 \mathrm{~g}(\mathrm{CV}=12,4 \%)$, were kept until 7 weeks. The experiment was designed as completely randomized design with 4 treatments and 5 replications. There were 6 birds each per experiment. Treatments applied were T1 (feeding a time a day, at 06.00 am), T2 feeding two times a day, at 06.00 am and 06.00 pm), T3 (feeding three times a day, at $06.00 \mathrm{am}, 12.00$ am and $06.00 \mathrm{pm}$ ), T4 (feeding four times a day, at $06.00 \mathrm{am}, 12.00 \mathrm{am}, 06.00 \mathrm{pm}$ and $12.00 \mathrm{pm}$ ). Parameters measured were protein efficiency ratio, meat protein mass and meat calcium mass. Data were analyzed according to analysis of variance (ANOVA) determine the effect of treatment. Different feeding frequencies were not significant $(P>0,05)$ on protein efficiency ratio, meat protein mass and meat calcium mass. Conclusion of this research explain different feeding frequencies against crossbred native chicken, didn't change the rate of protein efficiency ratio, meat protein mass and meat calcium mass.
\end{abstract}

Keywords : feeding frequencies, protein efficiency ratio, meat protein mass, meat calcium mass and crossbred native chicken.

\begin{abstract}
ABSTRAK
Penelitian ini bertujuan untuk mengevaluasi frekuensi penyajian ransum terhadap kualitas pertumbuhan yaitu rasio efisiensi protein, massa protein daging dan massa kalsium daging ayam kampung super (ayam kampung jantan dengan ayam ras petelur). Materi yang digunakan adalam ayam kampung super sebanyak 120 ekor umur 3 minggu yang diseragamkan bobot badan dengan rata rata 97,49 $\pm 5,40$ g/ekor dan diberi perlakuan selama 7 minggu. Rancangan yang digunakan yaitu rancangan acak lengkap (RAL) dengan 4 perlakuan dan 5 ulangan. Terdapat 6 ayam tiap percobaan. Perlakuan yang diuji sebagai berikut : T1 (frekuensi penyajian ransum 1 kali sehari, pukul 06.00 WIB), T2 (frekuensi penyajian ransum 2 kali sehari, pukul 06.00 dan $18.00 \mathrm{WIB}$ ), T3 (frekuensi penyajian ransum 3 kali sehari pukul 06.00, 12.00 dan 18,00 WIB) dan T4 (frekuensi penyajian ransum 4 kali sehari pukul 06.00, 12.00, 18.00 dan 24.00 WIB). Parameter yang diamati adalah rasio efisiensi protein, massa protein daging dan massa kalsium daging. Data yang diperoleh diuji dengan analisi ragam dan uji F. Frekuensi penyajian ransum yang berbeda tidak berpengaruh nyata $(\mathrm{P}>0,05)$ terhadap rasio efisiensi protein, massa protein daging
\end{abstract}


dan massa kalsium daging. Penelitian ini dapat disimpulkan bahwa frekuensi penyajian ransum yang berbeda terhadap ayam kampung super tidak merubah nilai rasio efisiensi protein, massa protein daging dan massa kalsium daging.

Kata kunci : penyajian ransum, rasio efisiensi protein, massa protein daging, massa kalsium daging, ayam kampung super.

\section{PENDAHULUAN}

Salah satu sumber protein hewani yang banyak dikonsumsi oleh masyarakat yaitu daging ayam buras. Upaya untuk meningkatkan produksi serta mempercepat pertumbuhan yaitu dengan menyilangkan dengan ayam unggul atau disebut Grading up. Model persilangannya yaitu ayam buras jantan digunakan untuk mengawinkan ayam ras petelur betina. (Sutiyono et al., 2006). Pertumbuhan yang kurang optimal ini dikarenakan pemberian pakan yang tidak sesuai dengan suhu nyaman ayam tersebut, sehingga energi dan protein dalam pakan yang dikonsumsi, tidak hanya digunakan untuk pertumbuhan tetapi juga digunakan untuk menyesuaikan suhu tubuh dengan suhu lingkungan. Penyajian ransum dengan frekuensi yang lebih banyak akan mampu memberikan kesempatan ayam untuk makan dengan makanan yang baru, sehingga mampu mendukung proses pencernaan didalam tubuh dan juga mampu meningkatkan pertumbuhan (Nova, 2008).

Pertumbuhan secara khusus, dapat dikategorikan menjadi 2 aspek yaitu aspek kualitas dan kuantitas. Penelitian ini menekankan pada kualitas pertumbuhan, berdasarkan kemampuan deposisi protein dalam bentuk massa protein daging. Kemampuan deposisi protein berhubungan erat dengan konsumsi ransum yang mengandung protein, sehingga mampu menjadi protein daging ( Bihan-Duval et al, 2008). Protein yang dikonsumsi oleh ayam dimanfaatkan untuk pertumbuhan jaringan tubuh dan hidup pokok (Scott et al., 1982). Perbandingan antara pertumbuhan dengan konsumsi protein disebut dengan rasio efisiensi protein (Situmorang et al., 2013). Pengaruh frekuensi penyajian ransum terhadap produktivitas, diuji berdasarkan jumlah protein yang mampu dideposisi oleh tubuh (massa protein daging).

Nilai massa protein daging dipengaruhi oleh keberadaan $\mathrm{Ca}$ dalam bentuk ion, karena ion $\mathrm{Ca}$ merupakan aktivator enzim pemecah protein yang disebut Calcium Activated Neutral Protease (CANP) dalam daging (Suthama, 1990). Penyerapan kalsium berhubungan dengan protein yang biasa disebut Calcium Binding Protein (CaBP). Perlakuan pada penelitian ini yaitu frekuensi penyajian ransum, memberikan kesempatan untuk ayam makan dengan ransum yang baru, sehingga ketertarikan ayam untuk mengkonsumsi ransum semakin tinggi. konsumsi ransum yang tinggi dalam sehari maka penyerapan protein dalam ransum semakin tinggi pula. Oleh sebab itu rasio efisiensi protein, massa protein dan massa kalsium daging yang digunakan sebagai parameter dalam penelitian ini merupakan indikator kualitas pertumbuhan akibat dari penyajian ransum yang berbeda.

\section{MATERI DAN METODE}

Penelitian frekuensi penyajian ransum yang berbeda terhadap ayam kampung super dilaksanakan pada 14 desember 2015 sampai dengan 3 Maret 2016 di Laboratorium Produksi Ternak Unggas, Fakultas Peternakan dan Pertanian, Universitas Diponegoro, Semarang. 
Materi yang digunakan yaitu ayam kampung super (persilangan antara ayam kampung jantan dengan ayam ras petelur) sebanyak 120 ekor unsexed dengan bobot badan rata rata 97,49 $\pm 5,40 \mathrm{~g}$ dipelihara selama 7 minggu dalam kandang dengan ukuran 70x100x150 cm.
Penelitian dilakukan secara eksperimental berdasarkan racangan acak lengkap (RAL) dengan 4 perlakuan dan 5 ulangan sehingga terdapat 20 unit percobaan, tiap unit percobaan diisi dengan 6 ekor ayam.

Tabel 1. Kandungan Nutrien Bahan Pakan

\begin{tabular}{|c|c|c|c|c|c|c|}
\hline Bahan Pakan & EM & PK & LK & SK & $\mathrm{Ca}$ & $\mathrm{P}$ \\
\hline & $\mathrm{kkal} / \mathrm{kg}$ & & -----. & $\%$ & 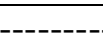 & \\
\hline Jagung Kuning & 3.677 & 7,40 & 2,02 & 0,99 & 0,47 & 0,09 \\
\hline Tepung Ikan & 1.939 & 27,82 & 17,28 & 14,72 & 3,89 & 2,60 \\
\hline PMM & 3.009 & 53,51 & 4,65 & 9,89 & 0,04 & 1,36 \\
\hline Bungkil kedelai & 3.462 & 38,19 & 2,03 & 2,41 & 3,00 & 1,69 \\
\hline Bekatul & 2.513 & 8,92 & 5,60 & 23,95 & 0,24 & 0,57 \\
\hline
\end{tabular}

Keterangan : Analisis proksimat di Laboratorium Ilmu Nutrisi dan Pakan, Fakultas Peternakan dan Pertanian, Universitas Diponegoro, Semarang (2015).

Tabel 2. Komposisi dan Kandungan Nutrien Ransum Perlakuan

\begin{tabular}{|c|c|}
\hline Komposisi Bahan Pakan & Persentase dalam ransum \\
\hline & ---- \\
\hline Jagung & 46,5 \\
\hline Tepung ikan & 9 \\
\hline PMM & 7,5 \\
\hline Bekatul & 18 \\
\hline Bungkil Kedelai & 18 \\
\hline Premix & 1 \\
\hline Total & 100 \\
\hline \multicolumn{2}{|l|}{ Kandungan Nutrien (\%) } \\
\hline Protein Kasar * & 18,44 \\
\hline Energi Metabolis $(\mathrm{kkal} / \mathrm{kg}) * * *$ & $3.185,38$ \\
\hline Serat Kasar* & 7,27 \\
\hline Lemak Kasar * & 4,22 \\
\hline Kadar Abu * & 7,08 \\
\hline Kadar Air * & 11,41 \\
\hline Kadar Kalsium Total $* *$ & 0,84 \\
\hline Kadar Phospor Total $* *$ & 0,75 \\
\hline
\end{tabular}

Keterangan:

* Berdasarkan Tabel 1. Komposisi Ransum Bahan Penyusun Ransum.

** Perhitungan berdasarkan kandungan nutrien bahan baku dari Tabel Hartadi, (1980).

*** Nilai perhitungan berdasarkan Carpenter dan Clegg, (1956) dalam Anggorodi (1985) $\mathrm{EM}=40,81\{0,87[\mathrm{PK}+2,25+\mathrm{LK}+\mathrm{BETN}]+2,5\}$

Perlakuan yang digunakan, yaitu :

T1 : Pemberian ransum 1 kali sehari pada pukul 06.00 WIB.
T2 : Pemberian ransum 2 kali sehari pada pukul 06.00 WIB dan 18.00 WIB. 
T3 : Pemberian ransum 3 kali sehari pada pukul 06.00 WIB, 12.00 WIB dan 18.00 WIB.

T4 : Pemberian ransum 4 kali sehari pada pukul 06.00 WIB, $12.00 \mathrm{WIB}$, 18.00 WIB dan 00.00 WIB.

Penerangan ruangan dengan lampu pada malam hari dihidupkan pukul 18.00 WIB dan akan dimatikan pada pukul 20.00 WIB, dinyalakan kembali pada pemberian ransum pukul 00.00 WIB - 02.00 WIB kemudian penerangan ruangan akan dimatikan hingga pukul 06.00 WIB.

Ransum yang digunakan sama untuk tiap perlakuan, diberikan dari umur 3 minggu hingga umur ayam 10 minggu. Bahan penyusun ransum terdiri dari jagung giling, tepung ikan, PMM (poultry meat meal), bekatul dan premix. Kandungan ransum dapat dilihat di Tabel 1 dan susunan ransum dapat dilihat pada Tabel 2.

Parameter yang diamati antara lain, rasio efisiensi protein, massa protein daging dan massa kalsium daging. Pengambilan parameter massa protein daging dan massa kalsium daging melalui uji lab mengenai kadar protein daging dan kadar kalsium daging. Uji kadar protein daging yaitu dengan metode mikro-kjehdhal, sedangkan massa kalsium daging diambil melalui uji Atomic Absorption Spectrofotometry (AAS).

Perhitungan massa protein daging (Suthama, 2003), dihitung berdasakan rumus berikut :

$\mathrm{MPD}=\mathrm{A} \times \mathrm{C}$

Keterangan :

MPD = Massa protein daging $(\mathrm{g})$

$\mathrm{A}=$ Kadar protein daging $(\%)$

$\mathrm{C} \quad=$ bobot daging $(\mathrm{g})$

Perhitungan massa kalsium daging (Suthama, 2003), dihitung berdasarkan rumus berikut :
$\mathrm{MKD}=\mathrm{B} \times \mathrm{C}$

Keterangan :

$\mathrm{MKD}=$ Massa kalsium daging $(\mathrm{mg} / 100 \mathrm{~g})$

$\mathrm{B}=$ Kadar kalsium daging $(\%)$

$\mathrm{C}=$ bobot daging $(\mathrm{g})$

Parameter rasio efisiensi protein diukur berdasarkan (Situmorang et al., 2013), dengan cara menghitung perbandingan antara pertambahan bobot badan dengan konsumsi protein.

$\mathrm{REP}=\mathrm{PBB} / \mathrm{KP}$

Keterangan :

REP $=$ Rasio efisiensi protein

$\mathrm{PBB}=$ Pertambahan bobot badan $(\mathrm{g})$

$\mathrm{KP}=$ Konsumsi Protein $(\mathrm{g})$

Data yang diperoleh dianalisis menggunakan analisis ragam (ANOVA), dengan uji $\mathrm{F}$, taraf 0,05 (Steel dan Torrie, 1993).

\section{HASIL DAN PEMBAHASAN \\ Konsumsi Protein}

Frekuensi penyajian ransum yang berbeda terhadap konsumsi protein tidak menunjukkan adanya pengaruh yang nyata $(\mathrm{P}>0,05)$. Konsumsi protein relatif sama dikarenakan konsumsi ransum tiap perlakuan juga relatif sama. Ransum yang diberikan pada semua perlakuan memiliki kandungan energi yang sama sehingga konsumsi ransum relatif sama, karena kebutuhan masing-masing ayam juga sama. Hal ini sesuai pendapat Swennen et al. (2004) bahwa kandungan energi dan protein yang sama pada ransum menyebabkan konsumsi ransum pada ayam akan cenderung sama.

Pemberian perlakuan penyajian ransum yang berbeda terhadap ayam kampung super mengindikasikan bahwa ayam kampung super dapat mengkonsumsi protein sesuai dengan kebutuhannya, walaupun diberikan penyajian ransum yang 
berbeda. Hasil dari penelitian ini, ayam kampung super yang mendapatkan perlakuan penyajian ransum siang hari, akan menurunkan konsumsi makan, tetapi akan memperbaiki kekurangan makan pada saat kondisi lingkungan sudah nyaman, yaitu di sore dan malam hari sehingga konsumsi protein tiap perlakuan sama. Menurut Fijana et al. (2012) bahwa penyajian ransum pada suhu lingkungan yang rendah dapat memperbaiki konsumsi yang rendah pada suhu lingkungan yang tinggi, dikarenakan suhu lingkungan yang tinggi akan meningkatkan konsumsi air minum daripada konsumsi ransum, sebagai upaya mengurangi tekanan panas dalam tubuh. Menurut Abdurrahman et al. (2013) bahwa ayam menyesuaikan diri dengan ransumya dengan cara mengkonsumsi lebih banyak protein pada ransum sehingga protein dalam tubuh dapat tercukupi.

Tabel 3. Rataan Konsumsi Protein, Rasio Efisiensi Protein, Massa Protein Daging dan Massa Kalsium Daging pada Masing Masing Perlakuan

\begin{tabular}{lcccc}
\hline Parameter & $\mathrm{T} 1$ & $\mathrm{~T} 2$ & $\mathrm{~T} 3$ & $\mathrm{~T} 4$ \\
\hline $\begin{array}{l}\text { Konsumsi protein } \\
\text { (g/ekor/minggu) }\end{array}$ & 64,64 & 59,34 & 64,90 & 61,05 \\
$\begin{array}{l}\text { Konsumsi kalsium } \\
\text { (g/ekor/minggu) }\end{array}$ & 2,98 & 2,91 & 2,91 & 2,78 \\
$\begin{array}{l}\text { Rasio Efisiensi Protein } \\
\text { Massa Protein Daging (g) }\end{array}$ & 1,75 & 1,82 & 1,72 & 1,89 \\
$\begin{array}{l}\text { Massa kalsium Daging } \\
\text { (mg/100 g) }\end{array}$ & 1,04 & 104,29 & 109,91 & 107,37 \\
\hline Kerangan & & 1,19 & 1,28 & 1,23 \\
\hline
\end{tabular}

Keterangan : Perlakuan tidak memberikan pengaruh yang nyata $(\mathrm{P}<0,05)$.

\section{Rasio Efisiensi Protein}

Rasio efisiensi protein antar perlakuan (T1, T2, T3 dan T4) tidak menunjukkan adanya pengaruh yang nyata $(\mathrm{P}>0,05)$. Nilai REP yang diperoleh antar perlakuan (T1, T2, T3 dan T4) relatif sama dapat dilihat pada Tabel 3, hal ini dikarenakan kandungan nutrien dalam ransum yang diberikan sama, selain itu juga hasil konsumsi protein yang relatif sama. Menurut Andhikasari et al. (2014), bahwa nilai rasio efisiensi protein yang sama disebabkan oleh kandungan protein ransum, komponen penyusun protein dalam ransum, konsumsi ransum, konsumsi protein, kualitas protein, kesimbangan asam-asam amino dan pertambahan bobot badan.

Penyesuaian dalam mengkonsumsi protein pada ayam dilihat dari tingkah laku makan ayam, kurangnya mengkonsumsi ransum pada siang hari atau suhu tinggi dan memperbaiki konsumsi ransum pada suhu yang rendah. Suhu lingkungan yang ekstrim atau panas untuk ayam, secara fisiologis, metabolisme tubuh ayam akan meningkat. Meningkatnya metabolisme tubuh ayam ini akan mempengaruhi konsumsi dan energi dalam daging untuk menstabilkan suhu tubuh dengan suhu lingkungan. Menurut Gordon (1994) bahwa, pemberian pakan pada malam hari dapat meningkatkan aktivitas makan ayam tetapi dapat mengurangi kesempatan ayam untuk istirahat. Menurut Ma'rifah et al. (2013) bahwa konsumsi ransum dipengaruhi oleh ketersedian nutrien terutama protein dan energi, jika ketersediaan nutrien seimbang maka efisiensi meningkat, selain itu suhu juga berpengaruh jika ayam terdapat pada suhu tidak nyaman maka penggunaannya 
sudah tidak efisien lagi, hal ini karena sejumlah energi yang masuk terpaksa digunakan untuk aktifitas fisiologis tubuh karena suhu yang tinggi. Zulkifi et al. (2000) menyatakan bahwa ayam yang mendapatkan pemberian ransum suhu lingkungan yang rendah menunjukkan adanya perbaikan efisiensi protein dan juga mampu mengurangi angka kematian.

\section{Massa Protein Daging}

Berdasarkan hasil analisis ragam massa protein daging antar perlakuan $\mathrm{T} 1$, T2, T3 dan T4 menunjukkan tidak adanya pengaruh yang nyata $(\mathrm{P}>0,05)$. Hasil yang diperoleh relatif sama dapat dilihat pada Tabel 3, hal ini dikarenakan proses deposisi protein hingga menjadi massa protein daging ini, ditunjang dari ketersediaan protein dalam ransum. Ketersediaan protein sebagai substrat dalam tubuh sangat berhubungan dengan metabolisme protein, khususnya dalam proses sintesis protein yang berdampak pada deposisi protein. Situmorang et al. (2013) berpendapat bahwa asupan protein berperan penting dalam proses deposisi protein melalui sintesis dan degradasi protein, konsumsi protein akan mempengaruhi asupan protein ke dalam daging.

Nilai massa protein daging yang sama pada setiap perlakuan, dikarenakan tingkah laku makan ayam yang mengurangi makan pada saat suhu lingkungan yang tinggi sehingga panas tubuh pada proses metabolisme dapat diatur secara baik. Selain itu suhu lingkungan di kandang juga mendukung untuk membentuk massa protein daging, diperoleh suhu rata-rata $27,85^{\circ}$ C. Menurut Yunianto et al. (1996) bahwa suhu antara $19-28^{\circ} \mathrm{C}$ mendukung untuk proses sintesis protein atau pembentukan massa protein daging, sedangkan suhu diatas $28^{\circ}$ mendukung untuk pemecahan protein dalam jaringan. Menurut Teasured et al. (2000) bahwa, suhu nyaman lingkungan pada ayam akan memacu proses sintesis protein khususnya deposisi protein, sehingga ayam cepat tumbuh dilihat berdasarkan bobot badan, tetapi usia juga dapat mempengaruhi proses sintesis protein, ayam yang sudah berumur kemampuan deposisi protein mulai menurun.

Terbentuknya massa protein daging ini dipengaruhi oleh beberapa faktor antara lain efisien dalam menggunakan protein. Nutrien yang diserap dari ransum digunakan untuk kebutuhan pokok dan produksi. Penyerapan nutrien yang baik dapat dilihat dari nilai efisiensi proteinnya. Penyajian ransum yang berbeda terhadap ayam kampung super, menunjukkan efisiensi penggunaan protein yang normal, maka dapat dikatakan penyerapan nutrien ayam kampung super baik, sehingga menghasilkan massa protein daging yang baik pula. Saraswati et al., (2015) menyatakan bahwa peningkatan massa protein daging dapat dilihat dari baik atau buruknya penyerapan nutrien, semakin tingginya efisiensi protein maka dapat memperbaiki produktivitas ayam. Menurut Kamran et al., (2008) bahwa, pertumbuhan, kandungan protein dalam daging dada dan paha dipengaruhi oleh tinggi rendahnya nilai rasio efisiensi protein juga.

\section{Massa Kalsium Daging}

Berdasarkan hasil analisis ragam massa kalsium daging antar perlakuan (T1, T2, T3 dan T4) menunjukkan tidak adanya pengaruh yang nyata $(\mathrm{P}>0,05)$. Hasil yang diperoleh relatif sama dapat dilihat pada Tabel 3. Hal ini dikarenakan massa kalsium daging dipengaruhi oleh konsumsi ransum dan konsumsi nutrient khusunya kalsium. Hasil konsumsi kalsium yang relatif sama 
pada penelitian ini, menyebabkan hasil massa kalsium daging juga relatif sama.

Penyajian ransum yang berbeda terhadap ayam kampung super menghasilkan nilai massa kalsium daging tiap perlakuan relatif sama. Hal ini juga disebabkan oleh massa protein daging. Hasil penelitian massa protein daging dengan penyajian ransum yang berbeda pada ayam kampung super menunjukkan massa protein daging yang sama pula dan termasuk tinggi, sehingga massa kalsium daging juga relatif sama dan nilainya termasuk rendah. Hal ini sesuai pendapat Suthama (1990) bahwa, apabila massa protein daging tinggi, maka massa kalsium daging rendah, dan sebaliknya, apabila massa kalsium daging tinggi, maka massa protein daging rendah. Menurut Tillman et al. (1991) bahwa, sebagian besar kalsium digunakan untuk pembentukan tulang, sisanya terdapat diluar jaringan tulang (dalam daging) yang berfungsi untuk proses metabolisme tubuh lain.

Kalsium yang diserap oleh tubuh yaitu berbentuk garam dalam daging dan juga berbentuk ion bebas yang berperan sebagai aktivator enzim protease. Ion bebas tersebut yaitu CANP (Calcium Activated Nuetral Protease). Menurut Ardiningsasi et al.(2007), CANP bertugas untuk membantu proses sintesis dan degradasi protein dalam tubuh sehingga dapat mennjadi media pertumbuhan daging yang baik. Menurut Abdurrahman et al. (2016) bahwa, kalsium dalam bentuk ion bebas yang rendah belum mampu mengaktifkan enzim protease untuk mendegradasi protein.

\section{KESIMPULAN}

Berdasarkan hasil penelitian, dapat disimpulkan bahwa penyajian ransum yang berbeda pada ayam kampung super tidak merubah nilai rasio efisiensi protein (REP), massa protein daging dan massa kalsium daging.

\section{SARAN}

Penentuan waktu penyajian ransum ayam harus tepat dan benar, sehingga perlu adanya kajian lebih lanjut mengenai waktu yang tepat untuk penyajian ransum ayam kampung super.

\section{DAFTAR PUSTAKA}

Abdurrrahman, Z. H., Y. B. Pramono dan N. Suthama. 2016. Feeding effect of inulin derived from dahlia tuber combined with Lactobacillus $s p$. On meat protein mass of crossbred kampong chicken. J. Indonesian trop. Anim. Agric. 41 (1) : $37-44$.

Andhikasari, K. B. Sukamto dan B. Dwiloka. 2014. Efisiensi penggunaan protein pada ayam

Ardiningsasi, S. M., Y. Maeda, S. Okamoto, T. Hashiguchi. 2007. Comparative studies of Ca-ATPase activity in epiphysis of tibia tarsus of quail line selected for body weight. Comp. Bichem. Physiol. $105: 219-222$.

Broiler Chickens. Kagoshima University, Kagoshima (Disertasi).

broiler dengan pemberian ransum mengandung tepung daun kayambang (Salvinia Molesta). J. Agripet 14 (2) : 76-83.

Fijana, M. F., E. Suprijatna dan U. Atmomarsono. 2012.Pengaruh proporsi pemberian pakan pada siang malam hari dan pencahayaan pada malam hari terhadap produksi 
karkas ayam broiler. J. Anim. Agric. 1 (1) $697-710$.

Gordon, S. H. 1994. Effects of day length and increasing day length programs on broiler welfare and performance. World's Poult. Sci. J. 50 : 269-282.

Kamran, Z., M. Sarwar., M. Nisa., M. A. Nadeem, S. Mahmod, M. E. Babar dan S. Ahmed. 2008. Effect of low-protein diets having constant energy to protein ratio on performance and carcass characteristics of broiler chickens from one to thrity five days age. Poult. Sci 87: 468-474.

Le Bihan-Duval, E., M. Debut, C. M. Berri, N. Sellier, V. SanteLhoutellier, Y. Jego and C. Beaumont. Chicken meat quality: genetic variability and relationship growth and muscle characteristics. BMC Genetics, 9:53

Ma'rifah, B., U. Atmomarsono dan N. Suthama. 2013. Nitrogen retention and productive performance of crossbred native chicken due to feeding effect of kayambang (Salvinia molesta). Internat. J. of Sci. and Eng. 5 (1) : 19-24.

Nova, K. 2008. Pengaruh perbedaan persentase pemberian ransum antara siang dan malam hari terhadap performans broiler strain cp 707. Animal Production, 10 (2) : $117-121$.

Poult. Sci. and Graduate School of Nutrition Cornell. University of Ithaca, New York.

Saraswati, A., N. Suthama dan V. D.Y. B. Ismadi. 2015. Penggunaan protein akibat pemberian porsi ransum berbeda dikombinasikan dengan lama pencahayaan pada ayam broiler. J. Anim. Agric. 4 (1) : $182-$ 189.

Scott, M. L., M. C. Nesheim, and R. J. Young. 1982. Nutrition of The Chicken. Dept. Of

Situmorang, N. A., L. D. Mahfudz, dan U. Atmomarsono. 2013. Pengaruh pemberian tepung rumput laut (gracilaria verrucosa) dalam ransum terhadap efisiensi penggunaan protein ayam broiler. $\mathrm{J}$. Anim. Agric. 2 (2) : 49-56.

Steel, R.G.D. dan J.H. Torrie. 1995. Prinsip Prosedur Statistik Suatu Pendekatan Biometrik. $4^{\text {th }}$. (Diterjemahkan oleh Sumantri, B). PT. Gamedia Pustaka Utama, Jakarta.

Suthama, N. 1990. Mechanism of Growth Promotion Induced bu Dietary Thyroxine in

Suthama, N. 2003. Metabolisme protein pada ayam kampung periode pertumbuhan yang diberi ransum memakai dedak padi fermentasi. J. Pengembangan peternakan tropis. Edisi spesial, : 44 - 48 .

Sutiyono, S. Riyadi dan S. Kismiati. 2006. Fertilitas dan daya tetas telur dari ayam petelur hasil inseminasi buatan menggunakan semen ayam kampung yang diencerkan dengan bahan berbeda. J. Indonesian Trop. Anim. Agric. 31 (1) : $36-40$.

Swennen Q., G. P. J. Janssens, E. Decuypere and J. Buyse. 2004. Effects of subtitution between fat and protein on feed intake and its regulatory mechanisms in broiler 
chicken : energy and protein

metabolism and diet-induced thermogenesis. Poult. Sci 83: $1997-$ 2004.

Tesseraud, S., A. M. Chagneau and J. Grizard. 2000. Muscle protein turnover during early development in chicken divergently selected for growth rate. Poult. Sci. 79 : 14651471.

Tillman, A. D., H. Hartadi, S. Reksohadiprodjo, S.

Prawirokusumo dan S. Lebdosoekojo. 1991. Ilmu Makanan Ternak Dasar. Cetakan Kelima. Gadjah Mada University Press, Yogyakarta.

Yunianto, V. D., K Hayashi, S. Kaneda, A. Ohtsuka dan Y. Tomita. 1996. Effect of environmental temperature on muscle protein turnover and heat production in tube fed broiler chickens. British Journal of Nutrition, 77:897-909.

Zulkifi, I., M. T. Norma, D. A. Israfand and A. R. Omar. 2000. The effect of early feed restriction on subquent response to high environmental temperatures in female broiler chickens. Poult Sci. 79 : 1401-1407. 